J. Clin. Chem. Clin. Biochem.

Vol. 20, 1982, pp. 761-764

\title{
A Selective Radioimmunoassay of Androstenedione in Plasma and Saliva
}

\author{
By Z. Putz
}

Institute of Endocrinology, Lubochña, Czechoslovakia,

R. Hampl

Research Institute of Endocrinology, Prague, Czechoslovakia,

A. Vañuga, J. Veleminský

Institute of Endocrinology, Lubochña, Czechoslovakia and

L. Stärka

Research Institute of Endocrinology, Prague, Czechoslovakia

(Received January 19/June 8, 1982)

Summary: A specific radioimmunoassay for 4-androstene-3,17-dione (androstenedione) based on rabbit antisera to $6 \beta$-hydroxy-4-androstene-3,17-dione-6-hemisuccinate-bovine serum albumin conjugate was developed. Cross reaction by testosterone was eliminated by addition of experimentally established amounts of testosterone antiserum, which cross reacted by only 0.004 with androstenedione. The method has been used for simultaneous determination of androstenedione in both plasma and saliva of normal women under basal conditions and following dynamic tests. The plasma levels in normal women averaged $3.6 \pm 0.9 \mathrm{nmol} / 1$ and correlated $(\mathrm{r}=0.93)$ with those found in saliva $(0.353 \pm 0.089 \mathrm{nmol} / 1)$.

\section{Radioimmunoassay für Androstendion in Plasma und Speichel}

Zusammenfassung: Für die Bèstimmung von 4-Androsten-3,17-dion (Androstendion) wurde ein spezifischer Radioimmunoassay ausgearbeitet. Antiserum gegen $6 \dot{\beta}$-Hydroxy-4-androsten-3,17-dion-6-hemisuccinat-Rindserumalbumin wurde an Kaninchen gewonnen. Die Kreuzreaktion mit Testosteron wurde durch eine Zugabe von Antiserum gegen Testosteron unterdrückt. Dieses Antiserum ergab eine nur 0.004 Kreuzreaktion mit Androstendion; die benötigte Menge wurde experimentell ermittelt. Die Methöde wurde zur Androstendionbestimmung in Blutplasma und Speichel bei normalen Frauen sowohl unter basalen Bedingungen als auch nach Provokations- und Hemmtesten verwendet. Die Mittelwerte der Androstendionkonzentration in Blutplasma der Frauen lagen bei $3.6 \pm 0.9 \mathrm{nmol} / 1$ und im Speichel bei $0.353 \pm 0.089 \mathrm{nmol} / 1 \mathrm{mit}$ einem Korrelationskoeffizienten von $\mathrm{r}=0.93$.

\section{.. Introduction}

Androstenedione is a precursor of both testosterone and oestrogens in testes and ovaries, the gonads being also claimed as a major source of the circulating hormone, at least in women (1). Its increase in early stages of puberty preceeds the appearance of higher testosterone levels (2) and it therefore may be an important indicator of sexual maturation.

Published radioimmunoassays use antibodies raised against androstenedione derivatives attached to a carrier protein through positions $3(3,4), 6(5), 11(6)$ or 19
(7). The pertinent problem with these methods remains the interference of cross reacting testosterone. According to Pratt et al. (8), this effect can be reduced considerably by addition to the system of a certain amount of antiserum against the competitor. We have tested this procedure, using testosterone antiserum, cross reacting by only 0.004 with androstenedione (9) for the radioimmunoassay of the latter in plasma and saliva. Antisera raised against androstenedione-6 $\beta$-hemisuccinate-bovine serum albumin and $11 \alpha$-hemisuccinate-bovine serum albumin were compared. 


\section{Materials and Methods}

\section{Stcroids}

$\left[1,2,6,7-{ }^{3} \mathrm{H}\right]$ Androstenedione and $\left[1,2,6,7-{ }^{3} \mathrm{H}\right]$ testosterone of specific radioactivities $3.18 \mathrm{TBq} / \mathrm{mmol}(86 \mathrm{Ci} / \mathrm{mmol})$ and $3.21 \mathrm{TBq} / \mathrm{mmol}(87 \mathrm{Ci} / \mathrm{mmol})$, respectively, from Radiochemical Centre, Amersham (England) were purified by paper chromatography in the system cyclohexane-toluene-methanol-water $(9+$ $1+8+2$ by volume). This system was also used in the assay for separation of androstenedione from testosterone.

$11 \beta$-Hydroxy-4-androstene-3,17-dione was prepared by alkali induced cleavage of the side chain of cortisol (10). Other nonradioactive steroids were purchased from Steraloids (Pawling, USA).

\section{Synthesis of immunogens}

The starting compounds, $6 \beta$-hydroxy-4-androstene-3,17-dione and $11 \alpha$-hydroxy-4-androstene-3,17-dione were prepared by oxidation of the dihydroxyacetone side chain of $6 \beta, 17 \alpha, 21$ trihydroxy-4-pregnene-3,20-dione and $11 \alpha, 17 \alpha, 21$-trihydroxy4-pregnene-3,20-dione ( $6 \beta$-hydroxycortisol and epicortisol, respectively) with sodium bismuthate (11). The identity of the products was confirmed by thin layer chromatography with small amounts of authentic steroids from Steraloids. The resulting $6 \beta$ - and $11 \alpha$-hydroxyandrostenediones were acylated with succinic anhydride in dry pyridine (12), and the hemisuccinates obtained were preparatively purified on thin layer silica gel (Merck F-254, Darmstadt, FRG) in ethyl acetate. The mixed anhydride method (13) was used for coupling these compounds to bovine serum albumin. The steroid/protein molar ratios were 21 and 6 for the $6 \beta$ - and $11 \alpha$-derivative, respectively.

Preparation of antisera

5 Month-old rabbits ( 3 animals for each conjugate) were immunized with the above antigens in complete Freund's adjuvantsaline mixture ( $1+1$ by volume) by intradermal injections $(1 \mathrm{mg}$ in $1 \mathrm{ml}$ ) at three-weeks intervals. The antiserum against testosterone-3-carboxymethyloxime-bovine serum albumin was raised previously (9).

\section{Sampling of plasma and saliva}

Blood was removed by venipuncture at 7 a.m. in 15 normal premenopausal women in the follicular phase. At the same time saliva (at least $2 \mathrm{ml}$ ) was collected and stored frozen at $=20^{\circ} \mathrm{C}$. Following thawing practically no emulsion occurred. Corticotropin stimulation in 6 normal women as performed by Synacthen ${ }^{\circledR}$ infusion $(0.25 \mathrm{mg}$ in $400 \mathrm{ml}$ of saline, Ciba, Basle, Switzerland) at 7 a.m., repeated on two successive days. Both blood and saliva were collected 8 hours after beginning of the infusion on each day. Dexamethasone suppression using Dexamethazon-Spofa (Czechoslovakia) was performed in 12 women. They were given $4 \times 0.5 \mathrm{mg}$ for the first two days and $4 \times 2 \mathrm{mg}$ during the third and fourth day. Blood and saliva were sampled at $7 \mathrm{a} . \mathrm{m}$. on the $3 \mathrm{rd}$ and 5 th day of the test. Human chorionic gonadotropin stimulation was performed in 12 normal women by two i.m. injections of $3000 \mathrm{I}$.U. of Praedyn-Spofa (Czechoslovakia), under simultaneous supression with dexamethasone ( $8 \mathrm{mg}$ for two days). Blood and saliva were collected on the morning of the second and third day of this test. The metyrapone test consisted of 6 oral doses of Metopirone (Ciba, Basle, Switzerland, 0.75 g every $4 \mathrm{~h}$ ) for $24 \mathrm{~h}$. Blood and saliva were collected 24 and 48 hours after the start of drug administration.

\section{Sample preparation}

Plasma $(400 \mu \mathrm{l})$ was extracted with diethyl ether $(4 \mathrm{ml})$ on the vortex mixer for $2 \mathrm{~min}$. Aliquots of the extract ( $500 \mu \mathrm{l}$, corresponding to $50 \mu \mathrm{l}$ of plasma) were transferred into test tubes and evaporated to dryness. Saliva $(1 \mathrm{ml})$ was extracted in the same way with $5 \mathrm{ml}$ of ether and $1 \mathrm{ml}$ portions of the extract (equivalent to $200 \mu$ of saliva) were taken for radioimmunoassay.

Radioimmunoassay

To the dry residues of extracts or to standard solutions of androstenedione $(0,6.25-400 \mathrm{pg}$ in $100 \mu \mathrm{l}$ of buffer $)$, the buffered solutions ( $100 \mu \mathrm{l} \mathrm{each})$ of the radioligand $(167 \mathrm{~Bq}$, i.e. $10000 \mathrm{~min}^{-1}$ ) and antisera mixture (anti-androstenedione-6 $\beta$ hemisuccinate-bovine serum albumin, working dilution 1:2000 + anti-testosterone-3-carboxymethyloxime-bovine serum albumin, working dilution 1:8000) were added successively, and the volume adjusted to $500 \mu \mathrm{l}$ with buffer $(50 \mathrm{mmol} / 1 \mathrm{Na}, \mathrm{K}$-phosphate, $\mathrm{pH} 7.4$, containing $0.078 \mathrm{~mol} / 1 \mathrm{NaCl}, 15.4 \mathrm{mmol} / \mathrm{l}$ sodium azide and $1 \mathrm{~g} / \mathrm{l}$ bovine serum albumin). The samples for determination of nonspecific binding and for the total radioactivity were processed in parallel. After mixing (vortex mixer), the samples were incubated at $37^{\circ} \mathrm{C}$ for $30 \mathrm{~min}$ and then in an ice bath for $1 \mathrm{~h}$. Bound and free fractions were separated by adding dextran-coated charcoal $(500 \mu \mathrm{l}, 0.25 \mathrm{~g} / 1$ Dextran $\mathrm{T}-70$ and $2.5 \mathrm{~g} / 1$ Norit A). The mixture was briefly vortexed, left to stand at $0{ }^{\circ} \mathrm{C}$ for $20 \mathrm{~min}$ and centrifuged. The radioactivity iñ $500 \mu \mathrm{l}$ of the supernatant was then measured.

\section{Miscellaneous}

All chemiçals were of analytical grade, diethyl ether was freed of peroxides and freshly distilled. Radioactivity was measured on Packard-Tricarb (USA) liquid scintillation spectrometer. The scintillation fluid consisted of $4 \mathrm{~g}$ PPO, $50 \mathrm{mg}$ POPOP and $20 \mathrm{ml}$ of methanol in 1 liter of toluene. The log-logit plot was routinely used for calculation of radioimmunoassay results.

\section{Results}

\section{Characterization of the antisera}

The rabbits were immunized with the above immunogens till at least one rabbit in each group responded with an antiserum titer of $10^{-4}$. This was achieved after 7 and 9 months, using the $6 \beta$ - and $11 \alpha$-immunogen, rêspectivèly. The specifity of both androstenedione antisera and of the testosterone antiserum added to the assay system, in terms of cross reactions with 16 hormonal steroids, are listed in table 1 . They were calculated from amounts of competing material causing $50 \%$ displacement of the radioligand according to Pratt (method $A$ ) (14). For radioimmunoassay purposes the $6 \beta$-antiserum was chosen, since it exhibited negligible cross-reaction with $11 \beta$ hydroxy-4-androstene-3,17-dione and showed practically no binding of cortisol; the cross-reaction of cortisol with $11 \alpha$-antiserum was too high to be ignored, in view of the cortisol concentrations in plasma and säliva.

\section{Estimation of the optimal concentration of testosterone antiserum}

The amount of testosterone antiserum to be added to the assay system was estimated experimentally according to Pratt (8), as the antiserum dilution at which the crossreaction of the chosen amount of the competitor (0.345 pmol i.e. $100 \mathrm{pg}$, corresponding to mid-values in analyzed samples) is less than 0.1 . As shown in table 2 , the working dilution 1:8000 fulfils this requirement. Under these conditions the calibration curves of androstenedione in the presence or absence of testosterone did not differ significantly. Using log-logit transformation, the following typical equations were obtained: without competitor $\mathrm{y}=3.86-1.01 \mathrm{x}$, with competitor and testosterone antiserum $y=4.10=1.16 \mathrm{x}$ (where $\mathrm{x}$ is the logarithm of androstenedione concentration). 
Tab. 1. Cross reactions of various steroids with rabbit antisera against $6 \beta$-hydroxy-4-androstene-3,17-dione-6-hemisuccinate-(6 $\beta$-derivative), $11 \alpha$-hydroxy-4-androstene-3,17-dione-11-hemisuccinate-(11 $\alpha$-derivative) and testosterone-3-carboxymethyloxime-(testosterone derivative) bovine serum albumin conjugates. $\left[{ }^{3} \mathrm{H}\right.$ ]androstenedione and $\left[{ }^{3} \mathrm{H}\right]$ testosterone were used as radioligands.

\begin{tabular}{|c|c|c|c|}
\hline Steroid & $6 \beta$-derivative & $11 \alpha$-derivative & $\begin{array}{l}\text { Testosterone } \\
\text { derivative }\end{array}$ \\
\hline $\begin{array}{l}\text { 4-Androstene-3,17-dione } \\
5 \alpha \text {-Androstane-3,17-dione } \\
5 \beta \text {-Androstane-3,17-dione } \\
\text { 4-Androstene-3,11,17-trione } \\
11 \beta \text {-Hydroxy-4-androstene-3,17-dione } \\
6 \beta \text {-Hydroxy-4-androstene-3,17-dione } \\
3 \alpha \text {-Hydroxy-5 } \alpha \text {-androstan-17-one } \\
\text { Testosterone } \\
17 \beta \text {-Hydroxy-5 } \alpha \text {-androstan-3-one } \\
3 \beta \text {-Hydroxy-5-androsten-17-one } \\
21 \text {-Hydroxy-4-pregnene-3,20-dione } \\
17 \alpha \text {-Hydroxy-4-pregnene-3,20-dione } \\
\text { Progesterone } \\
\text { Oestradiol } \\
\text { Aldosterone } \\
\text { Cortisol }\end{array}$ & $\begin{array}{l}1.00 \\
0.73 \\
0.69 \\
0.051 \\
0.002 \\
0.082 \\
0.07 \\
0.21 \\
0.04 \\
0.0063 \\
0.0054 \\
0.005 \\
0.009 \\
0.000004 \\
0.00003 \\
0.0007\end{array}$ & $\begin{array}{l}1.00 \\
0.43 \\
0.07 \\
0.75 \\
0.14 \\
0.013 \\
0.023 \\
0.22 \\
0.051 \\
0.0041 \\
0.0041 \\
0.0039 \\
0.0033 \\
0.0007 \\
0.0002 \\
0.0028\end{array}$ & $\begin{array}{l}0.0041 \\
0.0019 \\
\overline{0} \\
0.0024 \\
0.0029 \\
\overline{0} \\
0.0006 \\
1.00 \\
0.42 \\
0.0002 \\
- \\
\overline{0} \\
0.0003 \\
\overline{0} \\
\overline{0} .000004\end{array}$ \\
\hline
\end{tabular}

Tab. 2. The effect of various dilutions of testosterone antiserum added to the system containing $0.345 \mathrm{pmol}(100 \mathrm{pg})$ of testosterone and antiserum against 6 $\beta$-hydroxy-4-androstene-3,17-dione-6-hemisuccinate-bovine serum albumin (working dilution 1:2000). The cross reactivity of androstenedione with the above antiserum was 0.0042 .

\begin{tabular}{ll}
\hline Dilution of testosterone antiserum & $\begin{array}{l}\text { Relative binding of } \\
{\left[{ }^{3} \text { H]androstenedione }{ }^{\mathrm{a}}\right)}\end{array}$ \\
\hline No testosterone antiserum added & 0.807 \\
$1: 1000$ & 1.01 \\
$1: 2000$ & 0.970 \\
$1: 4000$ & 0.941 \\
$1: 8000$ & 0.905 \\
$1: 16000$ & 0.855 \\
$1: 32000$ & 0.830 \\
\hline
\end{tabular}

a) Related to binding of the radioligand to androstenedione antiserum alone without addition of competing testosterone.

\section{Reliability criteria of the method}

\section{Precision}

Tẅo plasma samples containing 3.4 and $6.2 \mathrm{nmol} / 1$ of androstenedione were assayed 20 times in one șeries and within 10 separate series. The coefficients of variation were 5.82 and $4.93 \%$ (intraassay) and 11.9 and $11.3 \%$ (interassay), respectively.

\section{Accuracy}

The average recoveries $(n=10)$ of 1.38 and $2.76 \mathrm{pmol}$ .. $(400$ and $800 \mathrm{pg}$ ) of androstenedione added to $400 \mu \mathrm{l}$ of plasma containing $3.47 \mathrm{nmol} / 1$ of endogenous hormone were 0.978 and 1.035 , respectively.

10 Plasma samples from healthy women with androstenedione concentrations ranging from 1.58 to $12.9 \mathrm{nmol} / \mathrm{l}$ (i.e. including samples from dynamic tests) were further assayed by three different procedures as follows:

1) The method described,

2) the same method but without addition of testosterone antiserum and
3) the above radioimmunoassay without addition of testosterone antiserum, after paper chromatography of the extracts.

In the latter case the results were corrected on the basis of the recovery of an added tracer $\left(16.7 \mathrm{~Bq}\right.$ of $\left[{ }^{3} \mathrm{H}\right]$ androstenedione per tube).

The following values were obtained (mean \pm S.D., in nmol/1):

1) $6.35 \pm 4.08$,

2) $7.92 \pm 5.54$,

3) $6.18 \pm 4.26$.

Using t-test for paired values, no significant differences were found between the results of the described method and those from the method with chromatographic separation of cross reacting testosterone. On the other hand, significantly higher concentrations $(\mathrm{P}<0.01)$ were measured when no testosterone antiserum was added to the assay system.

\section{Sensitivity}

The least detectable amount of androstenedione, calculated from repeated $(n=10)$ analysis of charcoal treated steroid-free plasma was $3 \mathrm{pg}(0.0105 \mathrm{pmol})$. The average $50 \%$ intercept of the calibration curve was $32 \mathrm{pg}(0.11 \mathrm{pmol})$ per tube.

Androstenedione concentrations in plasma and saliva

The basal concentrations of androstenedione in 15 normal premenopausal women in plasma and saliva as well as following four dynamic tests are summarized in table 3.

The plasma levels correlated well with those found in saliva within the whole region of values obtained. Regression analysis of the results of androstenedione concentration in plasma $(y)$ and saliva $(x)$ showed the equation 
Tab. 3. Concentration of androstenedione (in $\mathrm{nmol} / \mathrm{l}$ ) in plasma and saliva of normal premenopausal women and following four dynamic tests.

\begin{tabular}{|c|c|c|c|c|}
\hline \multirow[t]{2}{*}{ Sample } & \multicolumn{2}{|c|}{ Plasma } & \multicolumn{2}{|c|}{ Saliva } \\
\hline & $\mathrm{n}$ & $\overline{\mathbf{x}} \pm \mathrm{S} . \overline{\mathrm{D}}$. & $\mathbf{n}$ & $\overline{\mathbf{x}} \pm$ S.D. \\
\hline Basal levels & 15 & $3.62 \pm 0.90$ & $15^{\prime}$ & $0.35 \pm 0.0 .89$ \\
\hline \multicolumn{5}{|c|}{$\begin{array}{l}\text { Corticotropin } \\
(0.25 \mathrm{mg} \text { for each of } 3 \text { days })\end{array}$} \\
\hline $\begin{array}{l}\text { 1st day } \\
\text { 2nd day } \\
\text { 3rd day }\end{array}$ & $\begin{array}{l}6 \\
6 \\
6\end{array}$ & $\begin{array}{l}14.8 \pm 5.30 \\
15.8 \pm 5.91 \\
15.5 \pm 5.19\end{array}$ & $\begin{array}{l}5 \\
5 \\
5\end{array}$ & $\begin{array}{l}1.36 \pm 0.35 \\
3.15 \pm 1.84 \\
2.72 \pm 0.65\end{array}$ \\
\hline \multicolumn{5}{|c|}{$\begin{array}{l}\text { Dexamethasone } \\
\text { ( } 2 \mathrm{mg} \text { for } 2 \text { days followed by } 8 \mathrm{mg} \text { for the next } 2 \text { days) }\end{array}$} \\
\hline $\begin{array}{l}3 \text { rd day } \\
5 \text { th day }\end{array}$ & $\begin{array}{l}12 \\
12\end{array}$ & $\begin{array}{l}1.61 \pm 0.52 \\
1.60 \pm 0.34\end{array}$ & $\begin{array}{l}10 \\
10\end{array}$ & $\begin{array}{l}0.186 \pm 0.080 \\
0.157 \pm 0.053\end{array}$ \\
\hline \multicolumn{5}{|c|}{$\begin{array}{l}\text { Dexamethasone } \\
\text { ( } 8 \mathrm{mg} \text { for } 2 \text { days })+ \text { human chorionic gonadotropin ( } 3000 \text { I. U.) }\end{array}$} \\
\hline $\begin{array}{l}\text { 2nd day } \\
\text { 3rd day }\end{array}$ & $\begin{array}{l}12 \\
12\end{array}$ & $\begin{array}{l}3.00 \pm 0.64 \\
3.81 \pm 1.20\end{array}$ & $\begin{array}{l}10 \\
10\end{array}$ & $\begin{array}{l}0.254 \pm 0.067 \\
0.324 \pm 0.170\end{array}$ \\
\hline \multicolumn{5}{|c|}{$\begin{array}{l}\text { Metyrapone } \\
(6 \times 0.75 \mathrm{mg} \text { for } 24 \cdot \mathrm{h})\end{array}$} \\
\hline $\begin{array}{l}\text { 2nd day } \\
\text { 3rd day }\end{array}$ & $\begin{array}{l}5 \\
5\end{array}$ & $\begin{array}{r}15.0 \pm 3.72 \\
9.60 \pm 4.11\end{array}$ & & - \\
\hline
\end{tabular}

$y=0.17 x-0.22$ with the respective correlation $\mathbf{r}=0.931$.

\section{Discussion}

Though avoiding a chromatographic step, the method described is specific enough for routine measurement of androstenedione in biological fluids including saliva. The interference of testosterone is diminished by addition of an experimentally established amount of specific testosterone antiserum. Using androstenedione antiserum raised by an immunogen prepared through the $6 \beta$-position on the steroid molecule, the effect on the assay of $11 \beta$-hydroxyandrostenedione, an important steroid of exclusively adrenal origin $(4,12)$ may be neglected. Strongly cross reacting isomeric androstanediones are known as urine metabolites and occur in plasma only in negligible quantities. 17-Oxosteroids

\section{References}

1. Friedrich, E., Jaeger-Whilegiver, E. R., Bieder, M., Keller, E. \& Schindler, A. (1980) in Radioimmunoassay of Steroid Hormones (Gupta, D. ed.) pp. 91-100, Verlag Chemie, Weinheim.

2. Frasier, S. D., Gafford, F. \& Horton, R. (1969) J. Clin. Endocr. Metab. 29, 1404-1408.

3. Thorneycroft, I. H., Riberio, W. O. \& Stone, S. C. (1973) Steroids $21,111-122$.

4. Fiet, J., Gourmel, B., Villette, J. M., Brerault, J. L., Julieu, R., Cathelineau, G. \& Dreux, C. (1980) Hormone Res. 13, 133-149.

5. Parker, L. N., Grover, P. K. \& Odell, W. D. (1977) Steröids $29,715-724$.

6. Frölich, M., Termorshuizen, W., Kenter, E. \& Moolenaar, A. J. (1974) Steroids 24, 1-9.

7. Bermudez, J. A., Coronado, V., Miares, A., León, C., Velazgues, A., Noble, P. \& Mateos, J. L. (1975) J. Steroid Bio-
chem. 6, 283-290. are present in plasma as sulphates and are practically not extracted with most of organic solvents including diethyl ether.

The reliability criteria are within the limits usually obtained for radioimmunoassay. The basal levels of plasma androstenedione, as well as values obtained following dynamic tests, agree well with earlier reported data (1, $3,4,5,7)$. To our knowledge, our results are the first concerning the radioimmunological estimation of androstenedione in saliva. Assay of steroids in saliva rather than in plasma is no doubt advantagenous, especially in children, and also in the dynamic test, with serial collection of samples. As demonstrated, the concentrations of androstenedione in saliva are about one order of magnitude less than those measured in plasma. The values from dynamic tests follow the same pattern as in plasma.

8. Pratt, J. J., Woldring, M. G., Boonman, R. \& Wosman, W. (1979) Europ. J. Nucl: Med. 4, 171-177.

9. Hampl, R., Dvớák, P., Lukełová, Ș., Kozák, I., Chrpová, M. \& Stárka, L. (1978) J. Steroid Biochem. 9, 771-773.

10. Simons, S. J. Jr., Merchlinsky, M. J. \& Johnson, D. F. (1981) Steroids 37, 281-289.

11. Solo, A. J., Kapoor, J. N. \& Hebborn, P. (1970).J. Med. Chem. 13,751-754.

12. Ŕao, P. N., Moore, P. H. Jr. \& Goldzieher, J. W. (1974) Steroids 24, 793-801.

13. Erlanger, B. F., Borek, F., Beiser, S. M. \& Lieberman, S. (1959) J. Biol. Chem. 234, 1090-1094.

14. Pratt, J. J. (1978) Clin. Chem. 24, 1869-1890.

Dr. Z. Putz

Institute of Clinical Endocrinology ČS-034 91 Lubochřa 